\title{
Competence, Creativity, Productivity and Performance through Human Capital
}

\author{
Gina-Ionela Butnaru \\ Department of Economy and Business Administration, Alexandru Ioan Cuza University \\ Bulevardul Carol I, Nr.11, 700506 Iasi, Romania \\ T:+40 (232) 201453 gina.butnaru@uaic.ro
}

\begin{abstract}
Corina MATEI -GHERMAN
Department of Economy and Business Administration, Alexandru Ioan Cuza University

Bulevardul Carol I, Nr.11, 700506 Iasi, Romania

T:+40 (232) 201453 corina_matei_gherman@yahoo.uk.co
\end{abstract}

Accepted: January 30, 2012 Published: April 21, 2012

Doi:10.5296/ijhrs.v2i1.1678 URL: http://dx.doi.org/10.5296/ijhrs.v2i1.1678

\begin{abstract}
This work analyses a series of concepts regarding competence, creativity and productivity by the preparation of the future labour to become performant and creative, in order to support successfully and efficiently the future economy of the world.

In this paper we analysed implications of the European Union concerning the development of human resources by presenting the funds allocated in this purpose from 2007 to 2013.

The contribution of this work is of theoretical nature, and has the purpose to present as clearly as possible the necessity to invest in human resources in order to face the new requirements imposed by an economy based on knowledge, performance, and creativity.
\end{abstract}

Keywords: Competence, Creativity, Productivity, Performance, Human Capital

\section{Method and methodology}

For the realization of this work we studied the most important publications from the literature, scientific works, periodicals, technical and economic documentation, and other sources.

For this study we used documented research, but also exploratory research. We intended to identify and to survey the stage of knowledge, different approaches referring to the factors 
defining competence, creativity, productivity, performance and human capital (human resources).

\section{Introduction}

In the beginning of the $21^{\text {st }}$ century, a new economy era is about to make its appearance. This happens due to the challenges of the future which are bigger and bigger, among which some are even threatening the future development of human society, as the global raise of the population, and the consumption of the energy resources based on coal, oil, and natural gases, the food problem, the environmental pollution, the global climatic changes, the potable water resources, the nuclear catastrophes, etc.

Creative thinking, innovation, human performance, high productivity are the fundamental elements to assure the future development of human society. The creativity management of the implementation of future technology, as the nanotechnology, uses the concept of intellectual capital, by which the entire knowledge is defined, the engine of the changes which need to be made in the whole economic organisation of human society.

This transformation level, based mostly on knowledge in future society, defined as the knowledge society, involves mostly the human being, from the peak creative people to each employee of a company. The employees with innovative qualities will represent a decisive factor in the implementation of the nanotechnologies. They are people who, by their personal contribution, make the connection among research-development-industry-governmental decision factors.

The educated, innovative, creative, and competitive labour is the vector of progress towards the new from tomorrow, phenomenon by which the old economic structures are removed, making way to a new economic system, with higher performance, and greater productivity.

In what concerns the objective of European Union development, established in the year 2000 in Lisbon, to become until 2010 the most accomplished and competitive economy in the world, this is far of being reached. Un-development has increased, the financial and economic crisis is back, and the budgets of some member states show signs of weakness.

The cause of these threats should be sought within the companies which have not understood the role and the importance of the innovation and creativity process leading to a higher productivity on the capital market, generating social prosperity, though they possess enough resources to realise this objective.

If we account for 1000 employees, we notice that:

- In the European Union there are 5 research workers in 1000 employees;

- In the United States of America there are 8.3 research workers in 1000 employees;

- In Japan there are 9.6 research workers in 1000 employees.

In what concerns the existent research workers in the private companies, we notice the following situation: 
- In the European Union there are 2.4 research workers in 1000 employees;

- In the United States of America there are 5.9 research workers in 1000 employees;

- In Japan there are 6.3 research workers in 1000 employees.

These numbers explain to a great extent why the European Union economy is still not performant. Innovation as generating novelty elements is a conversion of new knowledge to the benefit of new economic and social development of the European Union to which we belong, and this has not been made yet obvious.

In the future economy of the knowledge society, the companies will not be able to increase their market share or to penetrate new global markets if they do not invest in technology, if they do not apply a creative management, a creativity strategy, a new method of creative management of human capital (human resource), and all these actions should develop under new rules, eliminating the existent ones from the present market.

\section{The stage of knowledge}

Competitiveness is a complex concept, long debated by the economists from the entire world. The notion of competitiveness is related to that of competition, and it expresses, at a general level, the capacity of companies, economies, regions, persons to maintain in the internal and/or international competition, and to obtain economic advantages, in the context of a specific business environment.

In professor Carbaugh's opinion (Washington University, 2009), "a company is competitive if it produces goods and services of higher quality or at a lower price than its internal or external competitors".

Competitiveness suggests security, efficiency, quality, high productivity, adaptability, success, modern management, low costs.

The true competitiveness is based on the establishment of continuous relationship with customers, so as the company to find out what the customers desire, and to be capable to use this information in order to stimulate innovation, and to offer services to the consumer's taste (Conti, Kondo, Watson, 2003).

The economist Kirsty Hughes (1993) defines two main approaches of the competitiveness concept:

- as an issue of relative, static or dynamic efficiency. This can be quantified on the basis of performance levels (the productivity level, the increase of the competitiveness, etc.);

- as a reflection of performances in international commerce (measured either under the form of the shares from the export markets, or the degree of import penetration).

Competitiveness can be analysed both globally, and at the level of each component. Thus, the specialists emphasised that global competitiveness of a company is determined by the competitiveness of each of the following categories of competitiveness: global, financial, human, managerial, technical, organisational, and commercial. 
Global competitiveness of a company depends on the good functioning of all its components, and it involves the realisation of a critical diagnosis of its capacity.

Financial competitiveness is expressed by a series of indicators: dimension of profit, capacity of self-financing, rentability, etc.

Human competitiveness is the result of labour quality, employment rate, skipping work rate, work level.

Commercial competitiveness is emphasised by the share of the market possessed, turnover evolution, customers' faithfulness, etc.

In order to define a company as competitive, a strict analysis is necessary, both of the company, and of its activity environment.

Competitiveness is determined by a series of factors (Nistoreanu, 2006), as follows:

- technical factors - referring to the technical characteristics of the service;

- financial factors - price or tariff, payment conditions;

- $\quad$ support factors - auxiliary services associated to a service, with the purpose to increase its added value;

- distribution/selling factors: delivery time, delivery conditions, distribution/delivery means;

- material factors: space, location, physical and communication infrastructure;

- intangible factors: innovation, information, knowledge, human resources' quality.

All these factors should be oriented towards the satisfaction of the customers' requirements and expectations to the greatest extent.

A company is competitive on a certain market when it succeeds to obtain certain economic indicators: turnover, profit, market share, market area, comparable or superior to those of other competitive companies, operating on the same market.

On long term, the services quality is the most important factor influencing the profit, and the most efficient way to increase the turnover, leading both to the market extension, and to the increase of the market share (Cetină, Brandabur, Constantinescu, 2006).

The quality issue has an important role in business, being associated with the competitive advantage assuring the company's profitability and survival (Dinu, 2009).

The companies activating in the services industry should confront with the competitors' offers, imposing up-to-date preoccupations concerning both competitive diversification, and services quality (Neacşu, Baron, Snak, 2006).

The services quality is a way to administrate a business with the purpose to assure the customers' total satisfaction, on all levels (internal and external). This approach leads to the increase of competitiveness, efficiency and flexibility of the whole company (Gržinić, 2007). 
A study realised by Skalpe and Sandvik (Jones, Haven-Tang, 2005) in 2002 confirmed the economic importance of services quality in a company. With the help of this study, we found evidence to support the fact that the long term effects of quality are more important than the short term effects.

The company managers are concerned that the services they offer are not very different from the competition's offers, especially if we consider that in tourism, in the hospitality industry respectively, competitiveness manifests also by way of the prices of the services offered.

One of the essential means of competitive differentiation is the constant provision of services whose qualitative level should be higher than other competitors' offers.

The role of quality in the realisation of the competitive advantage was demonstrated by several research studies in the years 1980'. A study done by PIMS Associates (Evans, 2004) demonstrated that:

- the service quality is the determinant factor of profitability;

- companies offering superior quality services usually have a higher market share, and enter the market easily;

- a strategy of quality improvement usually leads to the increase of the market share, but with a lower rentability cost;

- the producers of higher quality services can practise high prices.

Quality has positive effects over the company's economic performances, measured by the relative efficiency, the increase of the sales, and of the prices (tariffs).

There is a strong relationship among the perceived service quality, competitiveness, and customer's satisfaction. Consequently, the company should assure itself that it disposes of human capital, the main source of creation of the value in a service providing company.

The competitive companies know that the consumer's surprise arrives at the „moment of truth", when the service provider meets the consumer, implying the personnel's inspiration, perception, and spontaneity, qualities which should be encouraged and cultivated by managers. The customers are used with the routine of the service, with its usual characteristics, and they are surprised when the service providers offer them something different, meeting their desires, involving themselves in solving a problem, even if it is not among their attributions (Cetină, Brandabur, Constantinescu, 2006).

Quality is the basis for the realisation of the competitive advantage. The quality improvement of the services offered by the company leads to the customer's satisfaction, and to the company's benefit, both leading to the increase of the competitiveness.

\section{Directions of action for building an economy based on knowledge, competence, and creativity}

Let us remember that the dinosaurs that mastered the earth in the past have not been replaced by bigger and fiercer of their kind. Instead, in the evolution chain, smaller creatures appeared, 
being capable to adapt to the new climatic conditions, to evolve synthetically, being more inventive in a period of radical and rapid changes. It is this future that we are all confronting now, we need to change ourselves, to evolve, to adapt, or otherwise there is the risk of extinction at an individual, economic and social level.

The scenario is one of foreseeing. The companies should develop special social policies concerning human resources, taking into consideration the professional education development up to the top level. This creative evolution of the companies should lead to the increase of the degree of occupation of human resources established by the European Union to $70 \%$ in 2010 , decrease of the unemployment to $4 \%$, level reached in 2000 by the most performant economies in the world, and social inclusion, not the evolution towards exclusion. In other words: the main priority should be given to innovation and creativity in the entrepreneurship and companies, the basic cells where the economy based on knowledge and creativity is actually built.

The speed of the change rhythm is essential in the competition with the challenges of the future. We must be more productive. Synthetically, work productivity can be defined as the quantity of products realised in a unit of time, or the time necessary for the realisation of a product.

From this equation:

$$
P=\frac{Q}{T}, \quad \text { we are interested in time: }
$$

Where,

$$
\begin{aligned}
& \text { P - Work Productivity; } \\
& \text { Q - Quantity of products } \\
& \text { T - Time }
\end{aligned}
$$

For the future company based on knowledge and creativity, the increase of the productivity is essential. The specialists' approach concerning the definition of the productivity differs to a great extent.

Joseph Kesseles (2001) defines the knowledge productivity as the processing of the relevant information, generating new knowledge to be found in products and services reaching the market.

An approach closer to the economic reality and practice was promoted at the Conference organised by the Asian Productivity Organisation in Tokio, with the name: "Productivity in the electronic era", with the following concept: "productivity means what, how much, and how to produce, through the combination of the available resources with the purpose to improve the satisfaction of the customers' requirements". The approach of the work productivity should consider the relationship between the company and the customers, which is essential in the relationship process of the company involving the whole ensemble of the company.

A more complex vision over work productivity is the following: "as opposed to the situation 
from the industrial period when the maximum productivity was the only element taken into account, in the informational era everything refers to relationships" (Arora, 2002).

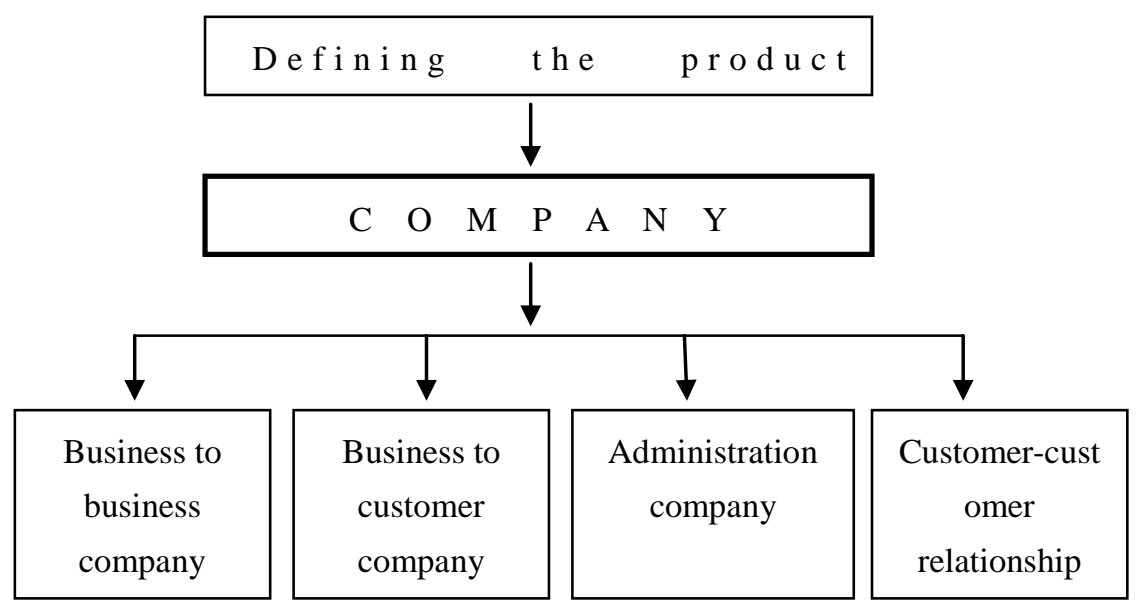

Figure 1. Relationships defining work productivity

In the battle with time, we should mention that the Chinese built in 2010 a 15 stories hotel in only six days, which is an astonishing productivity of the Chinese worker. A hotel in Romania begun also in 2010 is built in minimum 2-3 years. The level of productivity is of approximately 1 to 10 in the favour of the Chinese worker.

According to a study realised by Nomura Research Institute from Tokyo, and the Study Institute for South-East Asia from Singapore, in order to rapidly build an economy based on knowledge and creativity, we should operate in five directions:

- Development of informational technologies;

- Adaptability to the production and global consumption necessities;

- Increase of the role of research, innovation, and creation;

- Modernisation of the whole human potential, no matter the working place;

- Creative restructuring of the companies.

Man is the one who puts everything in motion by the use of his mind. However, he also needs to be "modernised" (top education). This objective can be reached by taking a few directions:

- Adoption of a different level of education and training, focused on quality, creativity, innovation, multilateral development of human resources, as a starting point for creative economy;

- Increase of the number of top specialists in the information technology;

- Attraction within the companies of the employees with abilities based on competences, knowledge and creativity, key elements for the companies' performance;

- Promotion of the top specialists' external image, through an adequate marketing message; 
- Reconsideration of the policies of immigration of performant labour and top specialists from their country of origin.

The specialty studies place Romania in the lower part of the classification of the economic performance. Consequently, Romania needs more than 20 years to recover the innovation difference and the differences between its economic development and the European Union's (Guckin, 2002).

According to the English specialists, for the realisation of the income per capita corresponding to the European Union, Romania will need approximately 80 years. The numbers are revolting. It should start immediately, the signal reads "go", and the ride is long and hard, and it requires creative work.

The company is the very place where performances are created, and the key element is the people, generically called human resources or human capital.

In the literature, there are several theories concerning the company in itself. The closest to reality is the theory of the company based on knowledge and creativity, recently created, starting from the following premises:

- A database about the knowledge acquired by the entire company;

- Development of the cognitive means of the company;

- Products innovation through knowledge;

- The knowledge capital should be the main resource;

- Competitive advantages should be acquired through knowledge, through practical valorisation of the specialised information.

Between 1995-1999, the companies based on knowledge and creativity obtained an increase of work productivity by $2.25 \%$, and of the places by $1 \%$, superior results being obtained by the European Union and Japan (Gheorghiu, Pâslaru, Turlea, 2004).

\section{The preparation of the future labour - a company necessity}

By the provisions of the European Union concerning the human resources development (HRD), through the departmental operational program of human resources development, the activities in this field are established, being financed from the European Social Fund in the convergence objective. The program consists of seven main axes as follows:

- Axis 1. Professional education and formation to support the economic growth and the development of the knowledge based society;

- Axis 2. Connection of the innovation with labour market all life long;

- Axis 3. The increase of the adaptability of labour and companies;

- Axis 4. Modernisation of the public service of occupation;

- Axis 5. Promotion of the active measures of occupation; 
- Axis 6. Promotion of social inclusion;

- Axis 7. Technical assistance.

The total budget allocated from 2007 to 2013 is of 188.66 million euros (Oprea, Meşniţă, 2007).

The durable increase is divided into two major components:

1.a. Competitiveness for labour growth and occupation;

1.b. Cohesion for labour growth and occupation.

The two components are in a strong interconnection, because both have the purpose to give an impulse to competitiveness, economic strength, and creation of new work places in the European Union. The European Social Fund contributes to the economic and social policy of the European Union by the improvement of labour quality and of employment opportunities. In this purpose, the fund comes to support the member states, operating for the increase of the workers' and organisations' adaptability, for a greater labour market access, for strengthening the social inclusion, for the disadvantaged persons, for fighting against discrimination, for the increase and the improvement of the investments in the human capital. Through the European Social Fund, financial support can be obtained for professional formation and reconversion activities. Consequently, two departmental operational programs are financed:

- Human Resources Development (POS HRD)

- Administrative Capacity Development (POS ACD)

Table 1. European funds from 2007 to 2013, Human resources development in professional education and formation*

\begin{tabular}{|l|l|}
\hline \multicolumn{1}{|c|}{ Name of the operation } & \multicolumn{1}{|c|}{ Eligible organisations } \\
\hline $\begin{array}{l}\text { Continuous formation of human resources } \\
\text { from high-schools, universities, CPF and } \\
\text { research }\end{array}$ & $\begin{array}{l}\text { Central and local administration, MECT, } \\
\text { MMFES, CNFPA structures, kindergartens, } \\
\text { TVED schools, high-schools, universities, RD } \\
\text { centres, ISJ, continuous formation providers. }\end{array}$ \\
\hline $\begin{array}{l}\text { "Outreach" and interdepartmental mobility } \\
\text { programs of formation and training of human } \\
\text { resources from education and research }\end{array}$ & $\begin{array}{l}\text { Research institutes and centres, MECT, } \\
\text { MMFES structures, National Council of } \\
\text { Rectors, CNFPA, kindergartens, TVED } \\
\text { schools, high-schools, universities, RD } \\
\text { centres, ISJ, continuous formation providers. }\end{array}$ \\
\hline $\begin{array}{l}\text { Support of the programs integrated for the } \\
\text { professors and research workers' reconversion }\end{array}$ & $\begin{array}{l}\text { AJOFM, ANOFM, MECT, MMFES, ANCS } \\
\text { structures, TVED schools, high-schools, } \\
\text { universities, ISJ, continuous formation } \\
\text { providers. }\end{array}$ \\
\hline $\begin{array}{l}\text { Support for the debut in the pedagogical } \\
\text { career and in research }\end{array}$ & \begin{tabular}{l} 
MECT, ANCS, ISJ structures \\
\hline Development of the young research workers'
\end{tabular} \\
\hline
\end{tabular}


* CNFPA - National Council of Professional Formation of Adults; RD - Research and Development; MECT - Ministry of Education, Research and Youth; MMFES - Ministry of Work, Family and Equal Chances; TVED - Technical and Vocational Education Development; CPF - Continuous Professional Formation

Table 2. European funds from 2007 to 2013, Quality in the continuous professional formation $(\mathrm{CPF})^{*}$

\begin{tabular}{|c|c|}
\hline & \\
\hline $\begin{array}{l}\text { Development of qualifications at } \\
\text { national, departmental and branch } \\
\text { level, and of the mechanisms of } \\
\text { evaluation of competences and } \\
\text { qualifications. }\end{array}$ & $\begin{array}{l}\text { Scheme A } \\
\text { National projects: MECT, MMFES, CNDIPT, CNFPA, } \\
\text { ARACIS, ARACIP, ISJ structures } \\
\text { Grant schemes: CNDIPT, CNFPA, ARACIS, } \\
\text { universities. }\end{array}$ \\
\hline $\begin{array}{l}\text { Implementation of assurance and } \\
\text { quality management systems in CPF } \\
\text { at system and provider level, in } \\
\text { accordance with the European } \\
\text { context for quality assurance. }\end{array}$ & $\begin{array}{l}\text { Scheme A } \\
\text { National projects: MECT, MMFES, CNDIPT, CNFPA, } \\
\text { ISJ ARACIS, ARACIP, ACPART structures } \\
\text { Scheme B } \\
\text { Individual projects: MECT, MMFES, CNFPA, } \\
\text { ARACIP structures } \\
\text { Grant schemes: CNDIPT, CNFPA, ARACIS, } \\
\text { universities. }\end{array}$ \\
\hline $\begin{array}{l}\text { ntation of the systems of } \\
\text { ole credits in } \mathrm{CPF}\end{array}$ & $\begin{array}{l}\text { Scheme A } \\
\text { National projects: MECT, MMFES, CNDIPT, CNFPA, } \\
\text { ISJ ARACIS, ARACIP, ACPART structures } \\
\text { Grant schemes: CNDIPT, CNFPA, ARACIS, } \\
\text { universities. }\end{array}$ \\
\hline $\begin{array}{l}\text { Realisation of studies, analyses and } \\
\text { research in order to gather } \\
\text { information and to promote the } \\
\text { exchange of good practices in CPF. }\end{array}$ & $\begin{array}{l}\text { Research institutes, MECT, MMFES, CNFPA } \\
\text { structures, continuous formation providers, business } \\
\text { organisations, chambers of commerce, SME }\end{array}$ \\
\hline $\begin{array}{l}\text { Increase of the capacity of } \mathrm{CPF} \\
\text { providing }\end{array}$ & $\begin{array}{l}\text { Central and local administration institutions, MMFES, } \\
\text { CNFPA structures, continuous formation providers. }\end{array}$ \\
\hline $\begin{array}{l}\text { Development of the partnership and } \\
\text { of the educational regions in } \mathrm{CPF}\end{array}$ & $\begin{array}{l}\text { Research institutes, MECT, MMFES, CNFPA, ISE } \\
\text { structures, continuous formation providers, business } \\
\text { organisations, chambers of commerce. }\end{array}$ \\
\hline
\end{tabular}

* AJOFM - County Agency for Labour Occupation; ANOFM - National Agency for Labour Occupation; ANCS - National Agency for Scientific Research; ARACIP - Romanian Agency of Quality Assurance in High-School Education; ARACIS - Agency of Quality Assurance in Superior Education; ACPART- National Agency for Qualification in Superior Education and Partnership with the Economic and Social Environment; CNDIPT - National Centre of Development of Professional and Technical Education; ISJ - County School 
Inspectorate; ISE - Institute of Science of the Education; SME - Small and Medium Enterprises; NGO - Nongovernmental Organisation.

Table 3. European funds from 2007 to 2013, Human resources development in professional education and formation. Total budget allocated to the field: 188.66 million euros

\begin{tabular}{|c|c|c|c|c|}
\hline $\begin{array}{c}\text { Main operation } \\
\text { field }\end{array}$ & $\begin{array}{c}\text { Value of the } \\
\text { projects }\end{array}$ & $\begin{array}{c}\text { Contribution } \\
\text { FSE } \\
(\%)\end{array}$ & $\begin{array}{c}\text { Contribution } \\
\text { Applicant } \\
(\%)\end{array}$ & $\begin{array}{l}\text { Financing } \\
\text { crossed with } \\
\text { other funds }\end{array}$ \\
\hline $\begin{array}{l}\text { Continuous } \\
\text { formation of } \\
\text { human } \\
\text { resources from } \\
\text { high-schools, } \\
\text { universities, } \\
\text { CPF and } \\
\text { research }\end{array}$ & $\begin{array}{l}\text { NPr: } 300,000-5 \\
\text { mil. euros } \\
\text { GC: } 500,000-5 \\
\text { mil. euros } \\
\text { IPr: } 50,000 \quad- \\
\text { 500,000 euros }\end{array}$ & 100 & 0 & FEDR \\
\hline $\begin{array}{l}\text { "Outreach" and } \\
\text { interdepartmental } \\
\text { mobility } \\
\text { programs of } \\
\text { formation and } \\
\text { training of } \\
\text { human resources } \\
\text { from education } \\
\text { and research }\end{array}$ & $\begin{array}{l}\text { NPr: } 300,000-5 \\
\text { mil. euros } \\
\text { GC: } 500,000-5 \\
\text { mil. euros } \\
\text { IPr: } \\
\text { 50,000-500,000 } \\
\text { euros }\end{array}$ & 100 & 0 & FEDR \\
\hline $\begin{array}{l}\text { Support of the } \\
\text { programs } \\
\text { integrated for the } \\
\text { professors and } \\
\text { research workers' } \\
\text { reconversion }\end{array}$ & $\begin{array}{l}\text { NPr: } 300,000-5 \\
\text { mil. euros } \\
\text { IPr: } \\
\text { 50,000-500,000 } \\
\text { euros }\end{array}$ & 100 & 0 & FEDR \\
\hline $\begin{array}{l}\text { Support for the } \\
\text { debut in the } \\
\text { pedagogical } \\
\text { career and in } \\
\text { research }\end{array}$ & $\begin{array}{l}\text { GC: } 500,000-5 \\
\text { mil. euros }\end{array}$ & 100 & 0 & FEDR \\
\hline
\end{tabular}

GC - Governmental Companies, IPr - International Project, NPr - National Project

Table 4. European funds from 2007 to 2013, Quality in continuous professional formation (CPF). Total budget allocated to the field: 174.52 million euros 


\begin{tabular}{|c|c|c|c|c|}
\hline Main operation field & $\begin{array}{l}\text { Value of the } \\
\text { projects }\end{array}$ & $\begin{array}{l}\text { Contribution } \\
\text { ESF }(\%)\end{array}$ & $\begin{array}{l}\text { Contribution } \\
\text { Applicant } \\
(\%)\end{array}$ & $\begin{array}{l}\text { Financing } \\
\text { crossed } \\
\text { with other } \\
\text { funds }\end{array}$ \\
\hline $\begin{array}{l}\text { Development of } \\
\text { qualifications at national, } \\
\text { departmental, and branch } \\
\text { level, and of their } \\
\text { mechanisms of evaluation } \\
\text { of competences and } \\
\text { qualifications }\end{array}$ & $\begin{array}{l}\text { NPr: } 300,000-5 \\
\text { mil. euros } \\
\text { GC: } 500,000-5 \\
\text { mil. euros }\end{array}$ & 100 & 0 & FEDR \\
\hline $\begin{array}{l}\text { Implementation } \\
\text { assurance systems and } \\
\text { quality management in } \\
\mathrm{CPF} \text { at system and } \\
\text { provider level, in } \\
\text { accordance with the } \\
\text { European context in order } \\
\text { to assure quality }\end{array}$ & $\begin{array}{l}\text { NPr:300,000- } 5 \\
\text { million euros } \\
\text { GC: } 500,000-5 \\
\text { mil. euros } \\
\text { IPr: } \quad 50,000 \\
-500,000 \text { euros }\end{array}$ & 100 & 0 & FEDR \\
\hline $\begin{array}{l}\text { Implementation of the } \\
\text { systems of transferable } \\
\text { credits in CPF }\end{array}$ & $\begin{array}{l}\text { NPr: } 300,000-5 \\
\text { mil. euros } \\
\text { GC: } 500,000-5 \\
\text { mil. euros }\end{array}$ & 100 & 0 & FEDR \\
\hline $\begin{array}{l}\text { Realisation of studies, } \\
\text { analyses and research in } \\
\text { order to gather } \\
\text { information and to } \\
\text { promote the exchange of } \\
\text { good practices in CPF. }\end{array}$ & $\begin{array}{l}\text { NPr: } 300,000-5 \\
\text { mil. euros } \\
\text { IPr: } \quad 50,000 \\
-500,000 \text { euros }\end{array}$ & $\begin{array}{c}100 \% \text { public } \\
\text { sector, NGO, } \\
\text { professional } \\
\text { non-profit } \\
\text { associations, } \\
\text { educational } \\
\text { system units, } \\
\text { authorities: } \\
70 \% \mathrm{SCE} \\
60 \% \mathrm{SE}\end{array}$ & $\begin{array}{l}0 \% \text { public } \\
\text { sector, NGO, } \\
20 \% \mathrm{SCE} \text {, } \\
40 \% \mathrm{SE}\end{array}$ & FEDR \\
\hline $\begin{array}{l}\text { Increase of the capacity of } \\
\text { CPF providing }\end{array}$ & $\begin{array}{l}\text { NPr: } 300,000-5 \\
\text { mil. euros } \\
\text { IPr: } \quad 50,000 \\
-500,000 \text { euros }\end{array}$ & 100 & 0 & FEDR \\
\hline $\begin{array}{l}\text { Development of the } \\
\text { partnership and of the } \\
\text { educational regions in } \\
\text { CPF }\end{array}$ & $\begin{array}{l}\text { NPr: } 300,000-5 \\
\text { million euros } \\
\text { IPr: } \quad 50,000 \\
-500,000 \text { euros }\end{array}$ & $\begin{array}{l}100 \% \text { public } \\
\text { sector, NGO } \\
\text { professional } \\
\text { non-profit } \\
\text { associations, } \\
\text { educational }\end{array}$ & $\begin{array}{l}0 \% \text { public } \\
\text { sector, NGO } \\
30 \% \mathrm{SCE} \text {, } \\
40 \% \mathrm{SE}\end{array}$ & FEDR \\
\hline
\end{tabular}




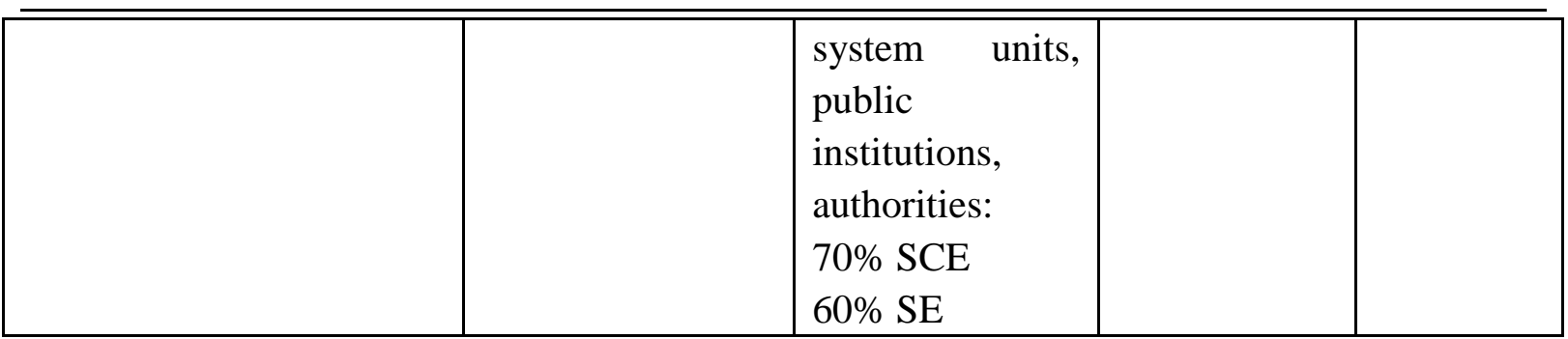

ESF - European Social Fund, SCE - Small Commercial Enterprises, SE - Small Enterprises

The company's creative resources are mainly its structure, performance and success.

The companies' productivity level has exhausted its drive, progress and evolution force, thus the necessity of radical changes, which concern:

- The accumulation of a larger volume of knowledge in the filed of activity, leading to work intellectualization and specialization on abilities, innovation and creative qualities, forming the company's elite, the so called "gold collar workers" or practitioners, who have the decisive role in obtaining performances;

- The use of persons with a limited knowledge on secondary functions, yet necessary to the company, the so called service personnel (Druker, 1993);

- The companies' appeal to the service personnel of other companies, through outsourcing some activities, but who contractually depend on other companies;

- The appeal to specialised agencies for performant personnel recruitment, when these resources are missing from the company;

- The approach according to which customers, providers, bankers, researchers, professors, lawyers, etc. with whom the company has a relationship should be among the actual human resources of the company.

The necessary changes in the human resources of the companies based on creativity and knowledge are also determined by the changes that take place on the labour market, as:

- Pierderea carierei and a posturilor in cazul desfiinţării companies.

- Reducing the occupancy time of certain jobs in the company's structures (contracts with a determined time period);

- Improved mobility of workers and specialists on the labour market;

- Employees' reduced loyalty towards the company;

- Hiring persons with innovation, creativity and performance tendencies;

- Hiring through specialised companies, on the basis of well determined performance criteria;

- The flexible motivation of specialists and workers; 
- Maintaining still a high inequality between the salaries and the human resource's hiring time;

- Careers and jobs losses when in the closing of a company.

However, there is a challenge distinguishing among the others, which can strengthen or destroy the future we are aiming to: the preparation of the future labour which should assure the productivity of the change, and the attraction of professional talents from outside the company, and for this a real war will start between the companies in the next period of time.

Today, the lack of specialists is being experienced in the field of high technology. Some obstacles which prevent the obtaining a highly qualified labour in the field of high technologies are the educational system on all levels, and the population aging tendencies, a phenomenon present in most of the countries in the world.

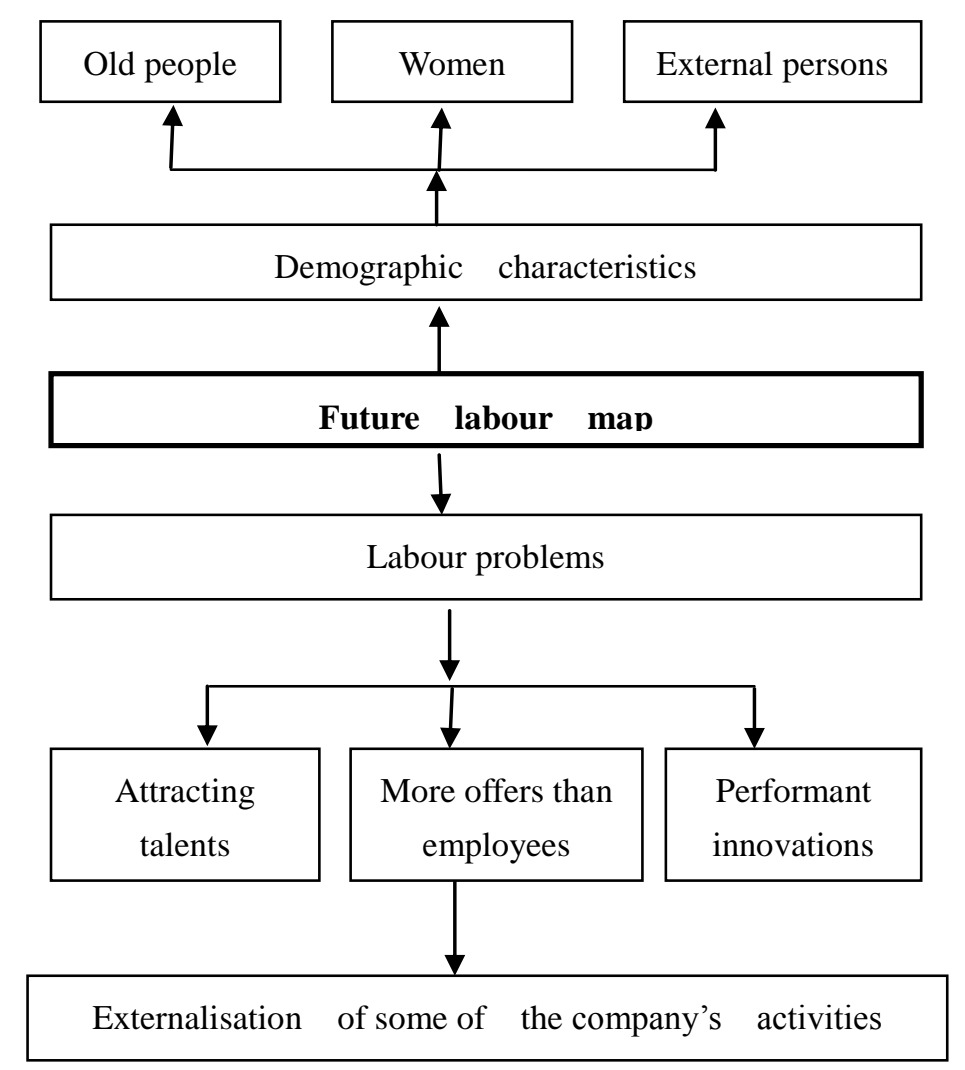

Figure 2. Future labour map

We have four scenarios for the preparation of the human resource for the future:

- Path openers. They are creative, innovative, performant, highly productive leaders, who are able to take the lead. They are best trained to confront the future obstacles, optimist, with a positive way of thinking, a clear perspective of the future, centred on technology, and extremely materialistic. They want for themselves interesting workplaces, a place in the company and in society, they have mathematical, informational, technological, and leadership aptitudes. Their capability and possibility to attract success is very high; 
- The group of traditionalists. They are the most numerous ones, their activity and aspirations are related to money and career, they are good family people, they are educated to reach an average level of success, they respect the traditional values of family, company and society. They do not have the tendency to become performant, innovative or creative leaders. This segment is mainly formed of women with higher education.

- The segment of the frustrated. They are persons unsure of their future, they do not have a higher education, and they have minimal chances to succeed in life or career. It is the least prepared segment for the confrontation with the future. They form the so called group of "those left behind", among which there are also a lot of young people in Romania. This social group needs to be given a chance, because they lack the necessary resources in order to reach their goals.

- The persons considered "activists". They are few, and they are the ones who go against the flow, trying to solve the things that do not work in economy and society. They are politically active, they are looking for the change, and have tendencies towards "discord" and destabilisation. They do not believe in the educational system, in the political orientation. They are disappointed in everything around them, taking fate in their own hands. They constitute a potential unpredictable factor, becoming socially destabilising elements. This human segment is manifested the same within the companies, and consequently the monitoring of this human group should be creative in order to cumulate the knowledge leading towards the company's performance.

At the same time with the four scenarios of the human resource development, some labour changes appear:

1. Labour changes at the population level. Next to the older persons, who have the experience and knowledge to assure the increased productivity, women will become major in the total of a company's employees, foreseeing that in the year 2025 one of three new employees will be a woman.

The natality decline will generate in some countries a deficit of highly productive labour, which will increase outsourcing, and creativity, talent and performance will become the companies' most valuable asset.

Those who will retire, also called the baby boomers generation, educated in high universities and having professional experience, will generate a crisis in Europe and U.S.A., which will be counterbalanced through immigration, and the new employees from outside will need to make high efforts to become performant and highly productive. The aging tendency of the population will determine in the future the migration of more than 100 million people from one part of the world to the other, with the tendency to compensate the resource in deficit, the creative work resource, professionally exceptional.

2. Changes in the labour generated by globalisation. It is considered that the outer afflux of qualified, professionally exceptional labour on the labour market of the European Union and other places, and its establishment in different geographical areas will become productivity key engines, and the countries' desire to have the most powerful economy in the 
world.

3. Changes of the labour generated by innovation. Occupying a position in a creative company will require in the future that the employer asks for a multidisciplinary education from its employee in what concerns high-tech, like those in the fields of: nano-bio-IT-neuro, etc. But this is only the beginning. In all the fields, innovation will be the key engine of the advantage against competition. The Romanian educational system cannot assure a highly productive and value adding labour, reason for which Romania's economy will require a longer period of time to become performant.

4. Changes of the labour at competitiveness level. Compared to the educational system in western countries, the Romanian educational system does not prepare accordingly the future labour to become competitive within the European Union and the global economy. This aspect justifies the slow rise of Romanian economic competitiveness, the low productivity and the tendency to outsource the performant workforce.

At international level, there is an operation made to attract talents, called "The hunt for human resources". Attracting talents takes proportions, and talented persons are being looked for, powerful people in order to face the challenges with which the companies are confronted. These talents come from the world of modern business, being familiarized with several cultures, speaking several languages, and they become unequalled values in a complex and global economic context. These persons' profile, the professional talents of the future will be as follows:

- The most intelligent, motivated and qualified persons;

- Qualified for the highest demands or requirements to take any job, anywhere in the global economy;

- They had the highest academic ranks in their year at one of the most prestigious universities in the world;

- Speciality master's and doctor's degrees;

- Speaking several worldwide circulation languages and being able to work in any country of the world;

- Feeling good in any country of the world, in any culture, in the presence of any customers, no matter their culture;

- At some first rate offers, they simply answer: "Thank you, but I am not interested. Have a nice day!"

- They can choose and find a leading job in any major city in the world.

In a creativity based company, possessing as much knowledge as possible is essential for reaching performance. In order to accumulate all this knowledge during their entire activity, if the employees wish to become performant and creative, they need to appeal to three sources of knowledge: their own, attracted, and bought. Most of the specialists in 
Romania mistake the company's knowledge with the knowledge of the person who accumulated it, thus neglecting the company's knowledge accumulated during the years of activity.

Each employee's own knowledge is the basis of the origin of the company's competitive advantage based on creativity;

The attracted knowledge (the attracted sources) which enriches and multiplies the employees' knowledge is represented by Internet, web-sites, electronic libraries, scientific reunions, fairs, exhibitions, etc., sources with low cost and easily accessible. In the western countries there are special structures within the companies, dealing with attracting knowledge.

The bought knowledge is the one for which certain persons are willing to give money in order to access. This is looked for especially by persons with a high level of training, and it refers to:

- Specialised studies, certain computer programs, projects, etc.

- Sending the employees once or twice a year to training courses, the costs being supported by the company;

- For the workers there are organised qualification courses, experience exchanges with similar companies, with the purpose to increase the volume of technological knowledge, with an effect in the increase of work productivity;

- The specialists from the company's intellectual elite have access to master's and doctor's degrees, post-doctoral training, research projects with international participation, scientific presentations, national and international congresses etc.

Introducing team work, building interdepartmental teams within the companies, the so called thinking groups, have proven very productive and creating an added value.

However, in order that the present labour becomes innovative, performant, creative, we need time which costs us money, and the change happens quickly. Painful changes will be necessary in the educational system, at the level of population structure, of immigration, and especially in the necessary labour education in order to be able to face the future challenges. One of the challenges will be the attitude towards the immigrants. In the U.S.A. alone, until the year 2015 there will be more workplaces than workers. The same tendency is manifested in the European Union.

The practice according to which the human resources must be regarded only at the level of the company or group of companies should be abandoned. Up to the present, the global human resources have sustained a demographical, statistical approach, mainly under a contemplative aspect, of acknowledging the phenomenon, without analysing the negative aspects of the world population growth, the solutions being limited at recommendations, aids, etc., lacking practical effectiveness.

The human resources issue must be treated interdisciplinary, through measures of influencing 
the evolution phenomenon, through demographical politics at national level, characterising the major lack of balance between the population growth and the available planetary resources. At the beginning of human history, the population was scanty, the quantity of life support means was not a problem, and the population growth was not alarming. Today, population growth gives rise to uneasiness and worry. The evolution of the population growth is presented as follows:

Table 5. Evolution of the population growth

\begin{tabular}{|l|c|c|c|c|c|c|c|}
\hline & $\mathbf{1 9 5 0}$ & $\mathbf{1 9 9 0}$ & $\mathbf{1 9 9 7}$ & $\mathbf{2 0 0 0}$ & $\mathbf{2 0 2 5}$ & $\mathbf{2 0 5 0}$ & $\mathbf{2 0 7 5}$ \\
\hline Total & 2524 & 5282 & 5849 & 6253 & 9065 & 11163 & 12210 \\
\hline Europe & 547 & 722 & 729 & - & - & - & - \\
\hline Romania & - & 22430 & - & - & - & - & - \\
\hline
\end{tabular}

Source: INS and Canton, 2010

The life expectancy in Romania is 65.5 to 73.3 years. Mircea Bulgaru, professor at the Academy of Economic Studies in Bucharest, states that: "If we relate the farmland to the existing population, at global level of 5.7 billion in the year 1995, it results a nourishment space (farmland) of 0.26 ha/inhabitant or 3.8 persons per hectare, with large differences over countries and continents".

In the year 2100, world population will double, and the standard farmland will be less than $0.13 \mathrm{ha} /$ person. In search for nourishment, the population of Africa and Asia will massively and violently migrate towards Europe and America, recreating at a much larger scale the migration of peoples. This migration is only at the beginning. For now, for certain religious and political reasons, "the demographical monster", as was called by the American genetician Norman Burlang, Nobel Peace Prize laureate in 1970, could not be stopped. Europe itself, in a not too far away future, could be suffocated by world population growth. Let us remember Thomas Robert Malthus, who in the year 1798 warned that the world population is multiplying in a geometrical progression 1.2.4.8.16.32..., and the resources in an arithmetical one 1.2.3.4.5.6... Malthus' merit consists in the fact that he was the first to signal the necessity of a close correlation necessary between the population and the means of life support.

In what concerns Romania, professor Mircea Bulgaru writes: "In the present stage, at country level, as production needs to be regulated, so needs to be the population." If not, the migrational phenomenon of a people will be stimulated, the result being the equalisation of the lower level of civilization.

\section{Conclusions,}

The human capital, considered the engine of a performant global economy, represents a very important source, which along its existence has been in a continuous transformation process both on a physical and an intellectual level.

Consequently, it is necessary to be educated in a certain rhythm, so as the global economies, the companies, etc., could register increasing values of performance indicators. 
As we presented above, the high performance level can be also registered by the increase of work productivity, leading also to the increase of competence level through human creativity.

The conclusion of the presentation is that the European Union allocates important funds to stimulate the development in the main resource of the global economy - the human capital, so as to become creative and performant in order to successfully and efficiently support the future economy of the world.

\section{Acknowledgement}

This work was supported from the European Social Fund through Sectoral Operational Programme Human Resources Development 2007-2013, project number POSDRU/1.5/S/59184 „Performance and excellence in postdoctoral research in Romanian economics science domain"

\section{References,}

Ali Akbar Ahmadi (2012), Role of the Social Capital in Effectiveness of Knowledge Management within Iran Khodro Diesel Company, International Journal of Learning \& Development, Vol. 2, No. 1

Arora, M., (2002), Productivity Improvements in SMEs, in XXX Productivity in e-Age, APO, Tokio

Burloiu, P., (2010), Managementul mondial al resurselor umane-o provocare, Independent Film, Bucharest

Butnaru, Gina, Ionela, (2009), Strategii manageriale pentru asigurarea calităţii produselor şi serviciilor turistice, Tehnopress, Iaşi

Carbaugh, R. (2009), International economics 12 edition, South-Western, Mason, p. 26

Canton, J., (2010), Provocările viitorului, Polirom, Bucharest

Cetină, I., Brandabur, R., Constantinescu, M. (2006), Marketingul serviciilor: Teorie and aplicatii, Uranus, Bucharest, pp. 59-64

Corodeanu, D., T., (2005), Management, comportamentul şi performanţa întreprinzătorului român, Tehnopress, Iaşi

Collins, J., (2007), Excelenţa în afaceri, Curtea Veche, Bucharest

Coman, Şt., G., (2008), Creativitate şi progres tehnic, PIM, Iaşi

Conti, T., Kondo, Y., Watson, G.H. (2003), Quality into the 21th century: perspective on quality and competitiveness for sustained performance, American Society for Quality, Milwaukee, p. 2

Dinu, V. (2009), Customer contribution to improving service quality in the hospitality industry, Amfiteatru Economic journal, vol. 11, p. 441

Druker, P., (1994), Management. Eficienţa factorului decizional, Destin, Bucharest 
Druker, P., (1993), Past-Capitalist Society, Buterwark Heinemann, Oxford

Eppler, M., (2008), Capcanele managementului, Polirom, Iaşi

Hughes, K. (1993), European competitiveness, Cambridge University Press, Cambridge, p. 1

Evans, J. (2004), Total Quality Management, Organization and Strategy, Thomson South-Western, Canada, p. 101

Gheorghiu, R., Pâslaru, D., Turlea, G., (2004), Competitivitatea pe bază de inovare a economiei româneşti in contextul Strategiei de la Lisabona, Open Society Institut, Bucharest

Guckin, R., (2002), Productivity in the e-Age American Experience, in XXX Productivity in e-Age, APO, Tokio

Gržinić, J. (2007), Concepts of service quality measurement in hotel industry, Economic thought and practice, no. 1, pp. 82-83

Jones, E., Haven-Tang, C. (2005), Tourism SMEs, service quality and destination competitiveness, CAB International, Massachusetts, p. 6

Joseph Kessels, (2001), Learning in Organisations: a Corporate Curriculum for the Knowledge Economy, Nederlanden, no. 33

Judit Beregszaszi, Dieu Hack- Polay, (2012), Human Resource Outsourcing in Times of Economic Turbulence - a Contemporary Review of Practice, International Journal of Human Resource Studies, Vol. 2, No. 1

Lache, C., (2001), Exigenţele economic-sociale privind gestiunea resurselor umane, Tipo Moldova, Iaşi

Maxwell, J., (2003), Dezvlotă liderul din jurul tău, Amaltea, Bucharest

Matei, Gherman, Corina, (2010), Marketing, Diferenţiere şi poziţionare, Tehnopress, Iaşi, Info-Tehnica, Kishinev, Moldova Republic

Nistoreanu, P. (2006), Calitate-Competitivitate: competitivitatea prin calitate, Amfiteatru Economic journal, vol. 20, p. 101

Niţă, V., (2004), Managementul serviciilor de cazare şi catering, Tehnopress, Iaşi

Neacşu, N., Baron, P., Snak, O. (2006), Economia turismului, Pro Universitaria, Bucharest, p. 392

Newton, R., (2009), Managementul schimbării, pas cu pas, ALL, Bucharest

Oprea, D., Meşniţă, G., (2007), Fonduri Europene pentru România 2007-2013, Sedcom Libris, Iaşi

Oyebamiji, M. A., Adekola, G (2012), Human Resource Development As a Tool For Empowering Grassroot Communities For Improved Community Development Programmes In Osun State, Nigeria, International Journal of Human Resource Studies, Vol. 2, No. 1 
Petcu, C., (1994), Impactul factorilor materiali asupra forţei de muncă, Scrisul Românesc, Craiova

Porumb, E., (2003), Modele şi strategii de formare şi ocupare profesională, EFES, Cluj Napoca

Rotaru, A., Prodan, A., (2001), Managementul resurselor umane, Sedcom Libris, Iaşi

Roca, M., (2001), Creativitate şi intelignţă emoţională, Polirom, Bucharest

Roşca, Al., (1981), Creativitate generală, specifică, Academiei, Bucharest

Sandu, S., (2002), Inovare competenţă tehnologică şi creştere ecconomică, Expert, Bucharest

Toma, V., Toma, R., M., (2009), Managementul creative şi inovativ în companiile româneşti, Tehnopress, Iaşi

White, E., (2009), Minte, caracter, personalitate, Viaţă şi sănătate, Bucureşti 